\title{
ERRATUM
}

To the paper

\section{ESTIMATION OF SULFUR IN COAL BY FAST NEUTRON ACTIVATION ANALYSIS}

G.C. Das, P.K. Bhattacharyya

Isotope Division, Bhabha Atomic Research Centre, Trombay, Bombay - 400 085, India

appeared in

Journal of Radioanalytical and Nuclear Chemistry, Letters, Vol. 201, No. 3 (1995) pp. 233-239.

We have noticed the following printing error in

the first line on page 237:

$R\left(g \mathrm{~cm}^{-2}\right)=0.53, \mathrm{E}(\mathrm{MeV})=0.106$

The line should read as:

$R\left(\mathrm{~g} \mathrm{~cm}^{-2}\right)=0.53 \mathrm{E}(\mathrm{MeV})-0.106$ 